Article

\title{
Cycloartane-Type Triterpenes and Botanical Origin of Propolis of Stingless Indonesian Bee Tetragonula sapiens
}

\author{
Niken Pujirahayu ${ }^{1,2} \mathbb{D}$, Toshisada Suzuki ${ }^{1}$ and Takeshi Katayama ${ }^{1, *}$ \\ 1 Laboratory of Biomass Chemistry, Faculty of Agriculture, Kagawa University, Kagawa 761-0795, Japan; \\ rahayuken08@gmail.com (N.P.); t-suzuki@ag.kagawa-u.ac.jp (T.S.) \\ 2 Department of Forestry, Faculty of Forestry and Environmental Sciences, Halu Oleo University, \\ Kendari 93232, Indonesia \\ * Correspondence: katayama@ag.kagawa-u.ac.jp; Tel.: +81-87-891-3083
}

Received: 6 February 2019; Accepted: 4 March 2019; Published: 8 March 2019

\begin{abstract}
This study clarifies the chemical constituents and botanical origin of Tetragonula sapiens Cockerell bee propolis collected from Southeast Sulawesi, Indonesia. Propolis samples and resin of Mangifera indica were extracted with 99\% ethanol to obtain an ethanol extract of propolis (EEP) and an ethanol extract of M. indica resin (EEM). Column chromatography, thin-layer chromatography (TLC), and high-performance liquid chromatography (HPLC) were developed and used for the separation and isolation of compounds from the ether-soluble fraction. The structure of the compounds was determined by nuclear magnetic resonance (NMR) spectroscopic analysis, and their molecular weight analyzed by gas chromatography-mass spectrometry (GC-MS). The HPLC chromatogram of the EEP was then compared with the HPLC chromatogram of EEM to investigate the botanical origin of propolis. Five compounds were isolated from the EEP, and their structures were determined as mangiferolic acid, cycloartenol, ambonic acid, mangiferonic acid, and ambolic acid, which are cycloartane-type triterpenes. The characteristic peak of the HPLC chromatograms of EEP and EEM showed a similar pattern, which is that the main components of propolis were also found in M. indica resin. These results suggested that the propolis from Southeast Sulawesi was rich in cycloartane-type triterpenes, and the plant source of the propolis could be Mangifera indica (mango).
\end{abstract}

Keywords: Tetragonula sapiens bee propolis; Southeast Sulawesi; cycloartane-type triterpene; botanical origin; Mangifera indica

\section{Introduction}

Propolis is one of the natural ingredients produced by honeybees, and it has been widely used as traditional medicine for a long period of time. It is a mixture of beeswax, resin, and other materials that are collected by honeybees like Tetragonula sapiens Cockerell, a kind of stingless bee, from plant buds, leaves, and exudates. Bees utilize propolis as building material for their nests as well as tools to prevent the growth of bacteria and fungi in the nest $[1,2]$. Specifically for stingless bees, propolis is also used to construct storage pots for pollen and honey [3].

Propolis contains a variety of compounds, such as (poly)phenols (flavonoids, phenolic acids, and their esters), terpenoids, steroids, amino acids, waxy acid, and sugars [4]. It has been reported that propolis has antioxidant, antimicrobial, antiparasitic [5], antiviral, anti-inflammatory [6,7], and anticancer [8] properties. A recent study also proved that propolis has antitoxic and antimutagenic activities [9].

All types of honeybees can produce propolis, but the generated amount of propolis is different depending on the genus or species and the flora of the region. The genus that generates a large 
amount of propolis is Tetragonula, which belongs to a group of stingless bees of the tribe Meliponini. Unlike Apis bees, Tetragonula bees are smaller than Apis bees, and have a non-functional stinger to defend against nest intruders, but use their jaws to bite them. There are more species of stingless bees than stinging honeybees. There are several hundred species that exist throughout the world that differ significantly in color, body size, and colony size [10,11]. The number of stingless-bee species is estimated to be more than 400 species, much more than that of honeybees that have stingers (11 species) [12]. T. sapiens Cockerell is a stingless-bee species in tropical regions. This species is found in Indonesia (Central Sulawesi [13] and Maluku), Philippine, New Guinea, Solomon Island, and Australia (Queensland) [14].

Studies of propolis components from stingless bees are still lacking, even though Apis mellifera species have been widely reported, especially in the Southeast Asia region. The propolis of a stingless bee from Brazil, Tetragonisca angustula, has triterpenes $\alpha$-amyrin and lanosterol, and benzophenones are major compounds of Melipona scutellaris [15,16]. The propolis of Tetrigona laeviceps and Tetrigona melanoleuca in Thailand contains a prenylated xanthone, $\alpha$-mangostin, and dipterocarpol, a dammarane triterpene [17]. The propolis of a Vietnamese stingless bee, Trigona timor, contains cycloartane-type triterpenes [18].

Propolis components and properties depend on its plant sources [19]. The cypress is the major plant source of Maltese propolis, and Populus bud exudates are the main sources of the propolis of Bologna, Italy, and Algeria. The resin of Macaranga tanarius L. and Mangifera indica L. is the source of propolis from Japan, Myanmar, and Vietnam [18,20]. Garcinia mangostana is the primary source of propolis from Thailand [17]. Trusheva et al. [21] have reported a propolis compound from the Apis mellifera honeybee of Indonesia, but the compounds of stingless-bee propolis are unknown, and the primary botanical source of these compounds has not yet been identified, especially in Sulawesi, Indonesia.

This study clarifies the chemical constituents of the Indonesian T. sapiens Cockerel bee propolis from Southeast Sulawesi, Indonesia, and their botanical origin.

\section{Results}

2.1. Main Compounds of T. sapiens Bee Propolis from Jatibali, South Konawe (P1) and Kendari District (P2), Southeast Sulawesi

The ether-soluble fraction of the $T$. sapiens bee propolis sample was subjected to a series of chromatographic-separation experiments giving two isolated compounds from P1 and three isolated compounds from P2. The former were mangiferolic acid (1) [22,23] and cycloartenol (2) [23]. The latter were ambonic acid (3) [23,24], mangiferonic acid (4), and ambolic acid (5) [23,25] (Figure 1a,b).

These compounds were identified by comparing their nuclear magnetic resonance (NMR) spectroscopic data (Tables 1 and 2) and their molecular weight (Table 3) with those in the literature.

Based on the NMR spectra data (Tables 1 and 2), all isolated compounds were included in the cycloartane triterpenes. A typical cyclopropane moiety characterizes this group. The presence of this bond is seen in the ${ }^{13} \mathrm{C}$ spectra and ${ }^{1} \mathrm{H}$ spectra (Figure S3).

The results of the mass-spectra calculations of the isolated compounds indicate that these compounds are cycloartane-type triterpenes with key fragmentation and their respective molecular formulas (Table 3).

Compounds 1 and 2 were present in more than $80 \%$ of the total area in the chromatogram obtained at $254 \mathrm{~nm}$ of the ether-soluble fraction of propolis from South Konawe (Figure 2 and Table 4); these two compounds are the main compounds of propolis P1, while other compounds are seen in small amounts. 


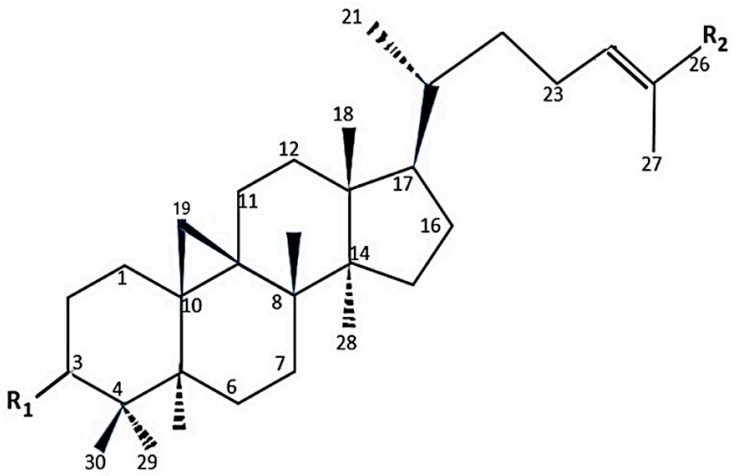

(a)

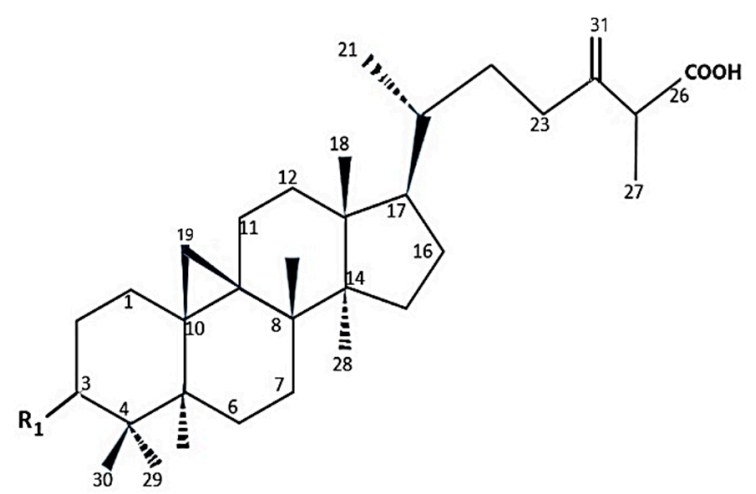

(b)

$1 \mathrm{R}_{1}=\beta-\mathrm{OH}, \mathrm{R}_{2}=\mathrm{COOH}$ (Mangiferolic acid) $2 \mathrm{R}_{1}=\beta-\mathrm{OH}, \mathrm{R}_{2}=\mathrm{CH}_{3}$ (Cycloartenol) $4 \mathrm{R}_{1}=\mathrm{O}, \mathrm{R}_{2}=\mathrm{COOH}$ (Mangiferonic acid) $5 \mathrm{R}_{1}=\beta-\mathrm{OH}$ (Ambolic acid)

Figure 1. Structures of isolated compounds from T. sapiens bee propolis in Southeast Sulawesi (a) compounds 1, 2, and 3; (b). Compounds 3 and 5.

Table 1. ${ }^{13} \mathrm{C}$ nuclear magnetic resonance $\left(\mathrm{NMR}, 150 \mathrm{MHz}\right.$ ) data in $\mathrm{CDCl}_{3}$ ( $\delta$ in ppm) for isolated compounds from T. sapiens bee propolis in Southeast Sulawesi.

\begin{tabular}{|c|c|c|c|c|c|}
\hline Carbon & $\begin{array}{l}\text { Mangiferolic } \\
\text { Acid (1) }\end{array}$ & $\begin{array}{c}\text { Cycloartenol } \\
\text { (2) }\end{array}$ & $\begin{array}{c}\text { Ambonic Acid } \\
\text { (3) }\end{array}$ & $\begin{array}{c}\text { Mangiferonic } \\
\text { Acid (4) }\end{array}$ & $\begin{array}{c}\text { Ambolic Acid } \\
\text { (5) }\end{array}$ \\
\hline 1 & 31.96 & 31.96 & 33.43 & 33.43 & 31.97 \\
\hline 2 & 30.36 & 30.39 & 37.48 & 37.48 & 30.36 \\
\hline 3 & 78.86 & 78.86 & 216.74 & 216.74 & 78.88 \\
\hline 4 & 40.48 & 40.49 & 50.25 & 50.25 & 40.48 \\
\hline 5 & 47.09 & 47.09 & 48.43 & 48.43 & 47.09 \\
\hline 6 & 21.11 & 21.11 & 21.51 & 21.51 & 21.11 \\
\hline 7 & 26.43 & 26.48 & 25.86 & 25.86 & 26.45 \\
\hline 8 & 47.96 & 48.49 & 47.87 & 47.87 & 47.98 \\
\hline 9 & 19.96 & 20.01 & 21.06 & 21.06 & 19.97 \\
\hline 10 & 26.07 & 26.02 & 25.97 & 25.97 & 26.01 \\
\hline 11 & 26.44 & 26.48 & 26.69 & 26.69 & 26.45 \\
\hline 12 & 32.89 & 32.89 & 32.79 & 32.79 & 32.91 \\
\hline 13 & 45.34 & 45.28 & 45.38 & 45.38 & 45.35 \\
\hline 14 & 48.81 & 48.80 & 48.75 & 48.75 & 48.82 \\
\hline 15 & 35.54 & 35.58 & 35.54 & 35.54 & 35.55 \\
\hline 16 & 28.15 & 28.14 & 28.15 & 28.15 & 28.15 \\
\hline 17 & 52.20 & 52.28 & 52.21 & 52.21 & 52.21 \\
\hline 18 & 18.07 & 18.03 & 18.11 & 18.11 & 18.07 \\
\hline 19 & 29.89 & 29.90 & 29.57 & 29.57 & 29.90 \\
\hline 20 & 35.97 & 35.88 & 45.37 & 45.37 & 35.98 \\
\hline 21 & 18.10 & 18.23 & 18.28 & 18.28 & 18.11 \\
\hline 22 & 34.79 & 35.01 & 34.7 & 34.7 & 34.8 \\
\hline 23 & 26.00 & 24.94 & 31.63 & 25.8 & 25.91 \\
\hline 24 & 145.74 & 125.26 & 148.68 & 145.69 & 148.67 \\
\hline 25 & 126.42 & 130.91 & 45.37 & 126.63 & 45.37 \\
\hline 26 & 172.01 & 17.65 & 179.80 & 172.82 & 179.78 \\
\hline 27 & 12.02 & 25.74 & 16.32 & 11.99 & 16.32 \\
\hline 28 & 19.31 & 19.31 & 19.29 & 19.29 & 19.32 \\
\hline 29 & 25.44 & 25.44 & 22.17 & 22.17 & 25.44 \\
\hline 30 & 14.00 & 14.00 & 20.78 & 20.78 & 14.02 \\
\hline 31 & & & 111.03 & & 111.08 \\
\hline
\end{tabular}


Table 2. ${ }^{1} \mathrm{H}$ NMR (600 MHz) data in $\mathrm{CDCl}_{3}$ ( $\delta$ in ppm) for isolated compounds from $T$. sapiens bee propolis in Southeast Sulawesi.

\begin{tabular}{|c|c|c|c|c|c|}
\hline Proton & $\begin{array}{c}\text { Mangiferolic } \\
\text { Acid (1) }\end{array}$ & $\begin{array}{c}\text { Cycloartenol } \\
\text { (2) }\end{array}$ & $\begin{array}{c}\text { Ambonic Acid } \\
\text { (3) }\end{array}$ & $\begin{array}{l}\text { Mangiferonic } \\
\text { Acid (4) }\end{array}$ & $\begin{array}{l}\text { Ambolic Acid } \\
\text { (5) }\end{array}$ \\
\hline 1 & $1.62 \mathrm{~m}, 1.24 \mathrm{~m}$ & $1.62 \mathrm{~m}, 1.24 \mathrm{~m}$ & $1.85 \mathrm{~m}, 1.54 \mathrm{~m}$ & $1.85 \mathrm{~m}, 1.54 \mathrm{~m}$ & $1.62 \mathrm{~m}, 1.24 \mathrm{~m}$ \\
\hline 2 & $1.75 \mathrm{~m}, 1.52 \mathrm{~m}$ & $1.75 \mathrm{~m}, 1.52 \mathrm{~m}$ & $2.73 \mathrm{~m}, 2.32 \mathrm{~m}$ & $2.73 \mathrm{~m}, 2.32 \mathrm{~m}$ & $1.75 \mathrm{~m}, 1.52 \mathrm{~m}$ \\
\hline 3 & $3.29 \mathrm{~m}$ & $3.29 \mathrm{~m}$ & - & - & $3.29 \mathrm{~m}$ \\
\hline 4 & - & - & - & - & - \\
\hline 5 & $1.33 \mathrm{~m}$ & $1.33 \mathrm{~m}$ & $1.71(\mathrm{~d}, 7.1)$ & $1.71(\mathrm{~d}, 7.1)$ & $1.33 \mathrm{~m}$ \\
\hline 6 & $1.49 \mathrm{~m}, 0.78 \mathrm{~m}$ & $1.49 \mathrm{~m}, 0.78 \mathrm{~m}$ & $1.57 \mathrm{~m}, 0.94 \mathrm{~m}$ & $1.57 \mathrm{~m}, 0.94 \mathrm{~m}$ & $1.49 \mathrm{~m}, 0.78 \mathrm{~m}$ \\
\hline 7 & $1.31 \mathrm{~m}, 1.12 \mathrm{~m}$ & $1.31 \mathrm{~m}, 1.12 \mathrm{~m}$ & $1.38 \mathrm{~m}, 1.14 \mathrm{~m}$ & $1.38 \mathrm{~m}, 1.14 \mathrm{~m}$ & $1.31 \mathrm{~m}, 1.12 \mathrm{~m}$ \\
\hline 8 & $1.55-1.62 \mathrm{~m}$ & $1.55-1.62 \mathrm{~m}$ & $1.56-1.59 \mathrm{~m}$ & $1.56-1.59 \mathrm{~m}$ & $1.55-1.62 \mathrm{~m}$ \\
\hline 9 & - & - & - & - & - \\
\hline 10 & - & - & - & - & - \\
\hline 11 & $2.03 \mathrm{~m}, 1.16 \mathrm{~m}$ & $2.03 \mathrm{~m}, 1.16 \mathrm{~m}$ & $1.97 \mathrm{~m}, 1.15 \mathrm{~m}$ & $1.97 \mathrm{~m}, 1.15 \mathrm{~m}$ & $2.03 \mathrm{~m}, 1.16 \mathrm{~m}$ \\
\hline 12 & $1.61-1.62 \mathrm{~m}, 2 \mathrm{H}$ & $1.61-1.62 \mathrm{~m}, 2 \mathrm{H}$ & $1.15-1.21 \mathrm{~m}, 2 \mathrm{H}$ & $1.15-1.21 \mathrm{~m}, 2 \mathrm{H}$ & $1.61-1.62 \mathrm{~m}, 2 \mathrm{H}$ \\
\hline 13 & - & - & - & - & - \\
\hline 14 & - & - & - & - & - \\
\hline 15 & $1.28-1.32 \mathrm{~m}, 2 \mathrm{H}$ & $1.28-1.32 \mathrm{~m}, 2 \mathrm{H}$ & $1.32-1.34 \mathrm{~m}, 2 \mathrm{H}$ & $1.32-1.34 \mathrm{~m}, 2 \mathrm{H}$ & $1.28-1.32 \mathrm{~m}, 2 \mathrm{H}$ \\
\hline 16 & $1.90 \mathrm{~m}, 1.27 \mathrm{~m}$ & $1.90 \mathrm{~m}, 1.27 \mathrm{~m}$ & $1.92-1.97 \mathrm{~m}$ & $1.92-1.97 \mathrm{~m}$ & $1.90 \mathrm{~m}, 1.27 \mathrm{~m}$ \\
\hline 17 & $1.58-1.61 \mathrm{~m}$ & $1.58-1.61 \mathrm{~m}$ & $1.68-1.72 \mathrm{~m}$ & $1.68-1.72 \mathrm{~m}$ & $1.58-1.61 \mathrm{~m}$ \\
\hline 18 & $0.97 \mathrm{~s}$ & $0.97 \mathrm{~s}$ & $1.00 \mathrm{~s}$ & $1.00 \mathrm{~s}$ & $0.97 \mathrm{~s}$ \\
\hline 19 & $\begin{array}{l}0.32(\mathrm{~d}, 4.1) \\
0.54(\mathrm{~d}, 4.1)\end{array}$ & $\begin{array}{l}0.32(\mathrm{~d}, 4.1) \\
0.54(\mathrm{~d}, 4.1)\end{array}$ & $\begin{array}{l}0.79(\mathrm{~d}, 3.6) \\
0.58(\mathrm{~d}, 3.4)\end{array}$ & $\begin{array}{l}0.79(\mathrm{~d}, 3.6) \\
0.58(\mathrm{~d}, 3.4)\end{array}$ & $\begin{array}{c}0.32(\mathrm{~d}, 3.5) \\
0.54(\mathrm{~d}, 3.5)\end{array}$ \\
\hline 20 & $1.28-1.32 \mathrm{~m}$ & $1.28-1.32 \mathrm{~m}$ & $1.41-1.44 \mathrm{~m}$ & $1.41-1.44 \mathrm{~m}$ & $1.28-1.32 \mathrm{~m}$ \\
\hline 21 & $0.91(\mathrm{~d} 6.6,3 \mathrm{H})$ & $0.91(\mathrm{~d} 6.6,3 \mathrm{H})$ & $(\mathrm{d}, 6.63 \mathrm{H})$ & $(\mathrm{d}, 6.6,3 \mathrm{H})$ & $(\mathrm{d}, 6.6,3 \mathrm{H})$ \\
\hline 22 & $1.55 \mathrm{~m}, 1.16 \mathrm{~m}$ & $1.55 \mathrm{~m}, 1.16 \mathrm{~m}$ & $1.58 \mathrm{~m}, 1.16 \mathrm{~m}$ & $1.58 \mathrm{~m}, 1.16 \mathrm{~m}$ & $1.55 \mathrm{~m}, 1.16 \mathrm{~m}$ \\
\hline 23 & $2.26 \mathrm{~m}, 2.16 \mathrm{~m}$ & $2.26 \mathrm{~m}, 2.16 \mathrm{~m}$ & $2.02 \mathrm{~m}, 1.92 \mathrm{~m}$ & $2.02 \mathrm{~m}, 1.92 \mathrm{~m}$ & $2.12 \mathrm{~m}, 1.95 \mathrm{~m}$ \\
\hline 24 & $6.88(t, 7.3)$ & $5.10(t, 7.1)$ & - & $6.90(\mathrm{bt}, 7.4)$ & - \\
\hline 25 & - & - & $3.16(\mathrm{bq}, 6.8)$ & - & $3.15(\mathrm{bq}, 6.8)$ \\
\hline 26 & - & $1.55 \mathrm{~s}$ & - & - & - \\
\hline 27 & $1.84 \mathrm{~s}$ & $1.05 \mathrm{~s}$ & $1.84 \mathrm{~s}$ & $1.84 \mathrm{~s}$ & $1.84 \mathrm{~s}$ \\
\hline 28 & $0.89 \mathrm{~s}$ & $0.89 \mathrm{~s}$ & $0.91 \mathrm{~s}$ & $0.91 \mathrm{~s}$ & $0.89 \mathrm{~s}$ \\
\hline 29 & $0.97 \mathrm{~s}$ & $0.97 \mathrm{~s}$ & $1.05 \mathrm{~s}$ & $1.05 \mathrm{~s}$ & $0.97 \mathrm{~s}$ \\
\hline 30 & $0.81 \mathrm{~s}$ & $0.82 \mathrm{~s}$ & $1.10 \mathrm{~s}$ & $1.10 \mathrm{~s}$ & $0.81 \mathrm{~s}$ \\
\hline 31 & & & $\begin{array}{l}4.97 \mathrm{bs} \\
4.93 \mathrm{bs}\end{array}$ & & $\begin{array}{l}4.97 \mathrm{bs} \\
4.93 \mathrm{bs}\end{array}$ \\
\hline
\end{tabular}

Table 3. Molecular ion and key fragmentation on mass spectra of identified compounds in T. sapiens bee propolis from Southeast Sulawesi.

\begin{tabular}{|c|c|c|c|}
\hline Compound Name & Retention Time (min) & Molecular Formula & Key Fragmentation $(m / z)$ \\
\hline Cycloartenol (2) & 41.99 & $\mathrm{C}_{30} \mathrm{H}_{50} \mathrm{O}$ & $\begin{array}{c}m / z 570(\mathrm{M}+2 \mathrm{TMS})^{+}, 483\left(\mathrm{M}+2 \mathrm{TMS}^{\left.-\mathrm{CH}_{3}\right)^{+}},\right. \\
408,393,135,109,95,73,69\end{array}$ \\
\hline Ambonic acid (3) & 47.64 & $\mathrm{C}_{31} \mathrm{H}_{49} \mathrm{O}_{3}$ & $\begin{array}{c}m / z 612(\mathrm{M}+2 \mathrm{TMS})^{+}, 540\left(\mathrm{M}+2 \mathrm{TMS}-\mathrm{CH}_{3}\right)^{+}, \\
394,313,189,175,107,95,73\end{array}$ \\
\hline Mangiferonic acid (4) & 48.67 & $\mathrm{C}_{30} \mathrm{H}_{47} \mathrm{O}_{3}$ & $\begin{array}{c}598(\mathrm{M}+2 \mathrm{TMS})^{+}, 526\left(\mathrm{M}+2 \mathrm{TMS}-\mathrm{CH}_{3}\right)^{+}, 421, \\
388,311,189,133,107,95,73\end{array}$ \\
\hline Mangiferolic acid (1) & 49.13 & $\mathrm{C}_{30} \mathrm{H}_{49} \mathrm{O}_{3}$ & $\begin{array}{c}m / z 600(\mathrm{M}+2 \mathrm{TMS})^{+}, 585\left(\mathrm{M}+2 \mathrm{TMS}-\mathrm{CH}_{3}\right)^{+}, \\
510,495,467,135,95,73,44\end{array}$ \\
\hline Ambolic acid (5) & 49.14 & $\mathrm{C}_{31} \mathrm{H}_{49} \mathrm{O}_{3}$ & $\begin{array}{c}m / z 616(\mathrm{M}+2 \mathrm{TMS})^{+}, 585\left(\mathrm{M}+2 \mathrm{TMS}-\mathrm{CH}_{3}\right)^{+}, \\
510,495,467,135,95,73\end{array}$ \\
\hline
\end{tabular}

The results of the HPLC chromatogram indicate that propolis from Kendari (P2) contains compounds that are more diverse than Jatibali propolis (P1). Compounds 3, 4, and 5 dominate propolis from Kendari (P2), with more than $36 \%$ of the total area in the chromatogram obtained at $254 \mathrm{~nm}$ of the ether-soluble fraction in this propolis (Figure 3 and Table 5). 


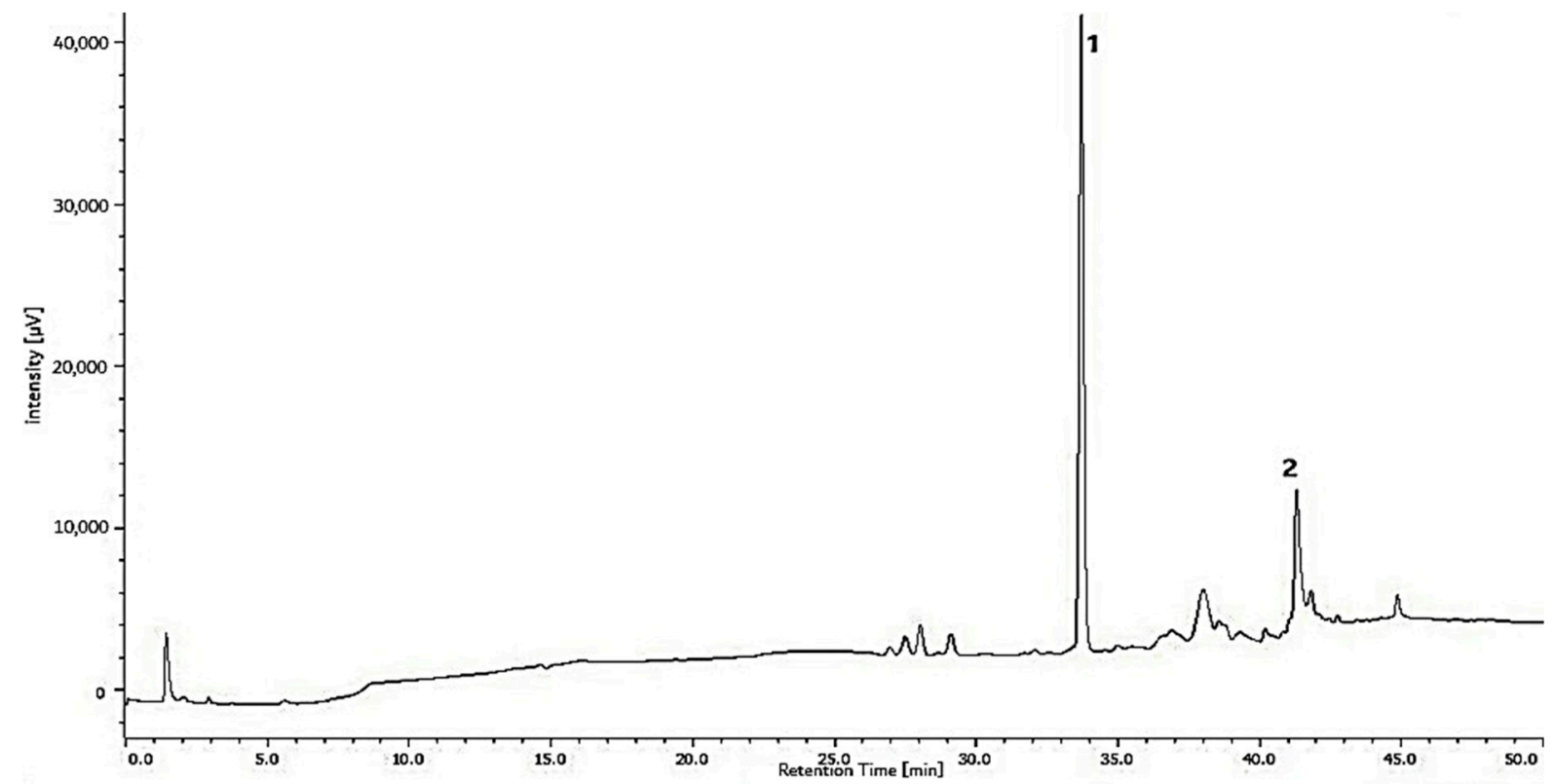

Figure 2. High-performance liquid chromatography (HPLC) chromatogram of the ether fraction of P1 (T. sapiens propolis from Jatibali, South Konawe district, Southeast Sulawesi); (1) mangiferolic acid and (2) cycloartenol.

Table 4. Distribution of cycloartane-type triterpenes in the T. sapiens bee P1 propolis (from Jatibali, South Konawe district, Southeast Sulawesi).

\begin{tabular}{ccccc}
\hline Compound Number & Compound Name & Retention Time (min) & Wave Length (nm) & Area (\%) \\
\hline $\mathbf{1}$ & Mangiferolic acid & 33.68 & 254 & 80.25 \\
$\mathbf{2}$ & Cycloartenol & 42.15 & 254 & 8.87 \\
\hline
\end{tabular}

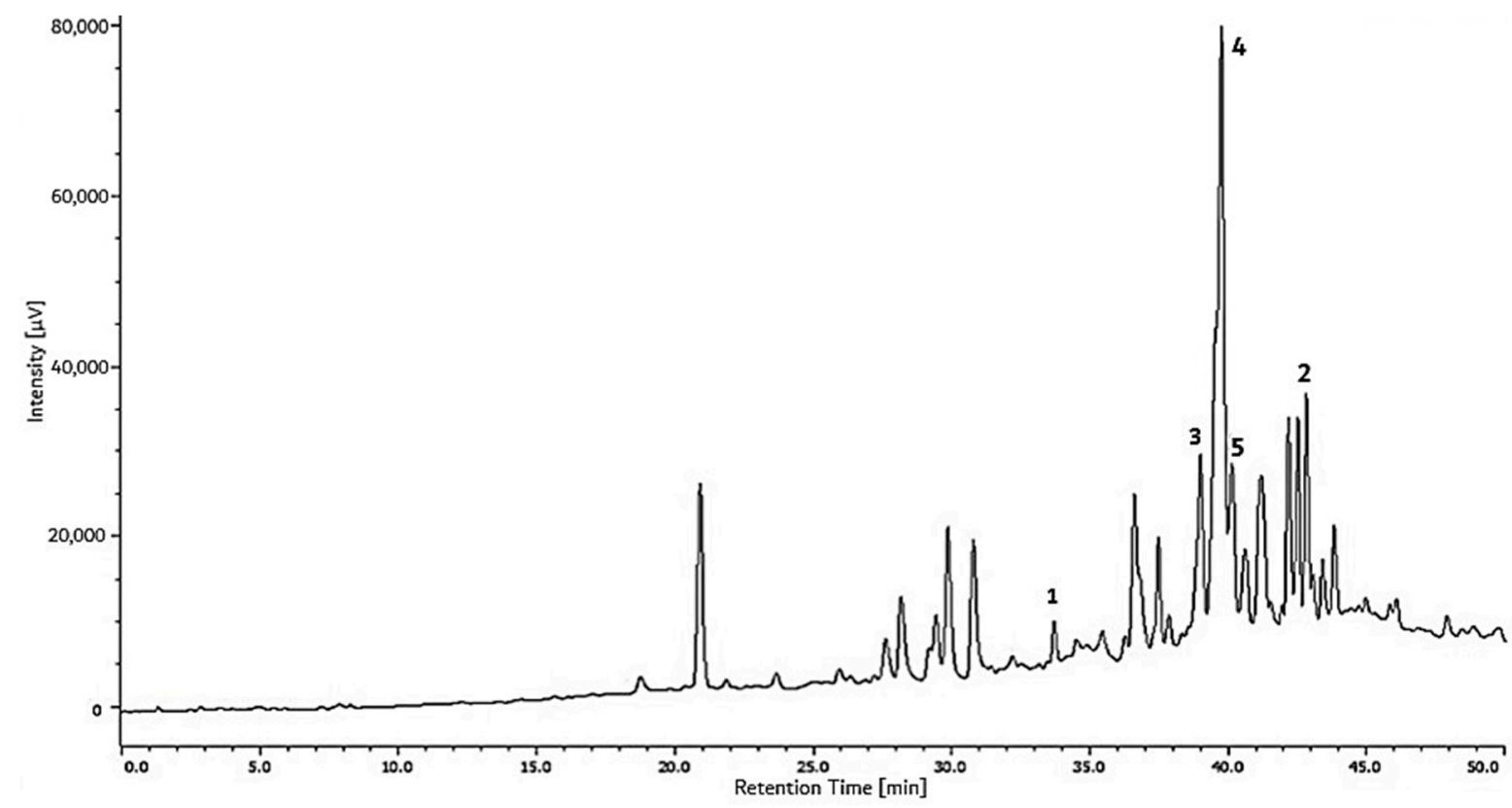

Figure 3. HPLC chromatogram of ether fraction of P2 (T. Sapiens propolis from Kendari district, Southeast Sulawesi); mangiferolic acid (1), cycloartenol (2), ambonic acid (3), mangiferonic acid (4), and ambolic acid (5). 
Table 5. Distribution of cycloartane-type triterpenese in the T. sapiens bee P2 propolis (from Kendari district, Southeast Sulawesi).

\begin{tabular}{ccccc}
\hline Compound Number & Compound Name & Retention Time (min) & Wave Length (nm) & Area (\%) \\
\hline $\mathbf{3}$ & Ambonic acid & 38.97 & 254 & 11.32 \\
$\mathbf{4}$ & Mangiferonic acid & 39.72 & 254 & 22.6 \\
$\mathbf{5}$ & Ambolic acid & 40.09 & 254 & 2.9 \\
\hline
\end{tabular}

\subsection{Botanical Origin of Propolis}

The comparison between the main propolis components with the main components of mango resin can be seen in Figure 4A-C.
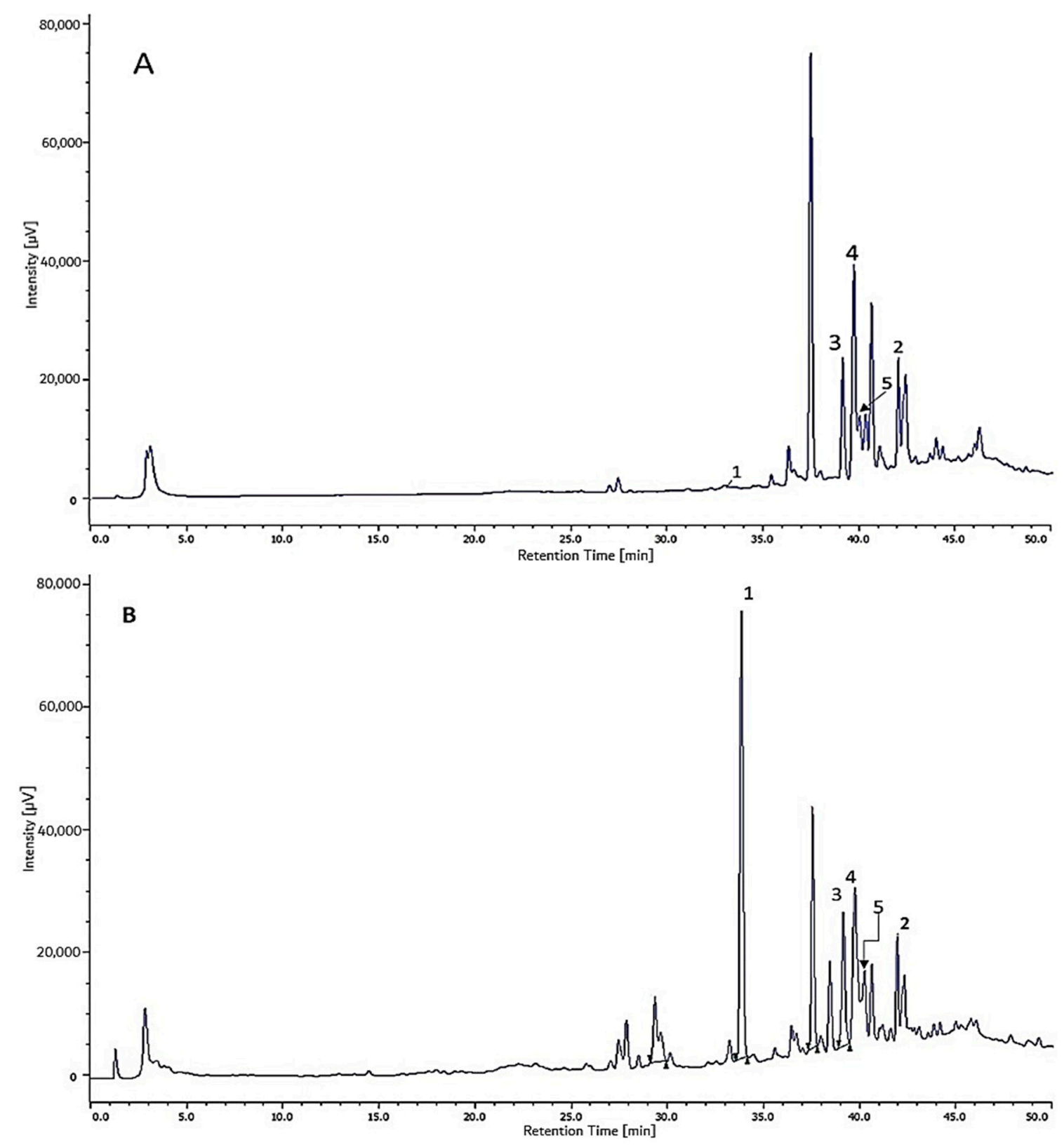

Figure 4. Cont. 


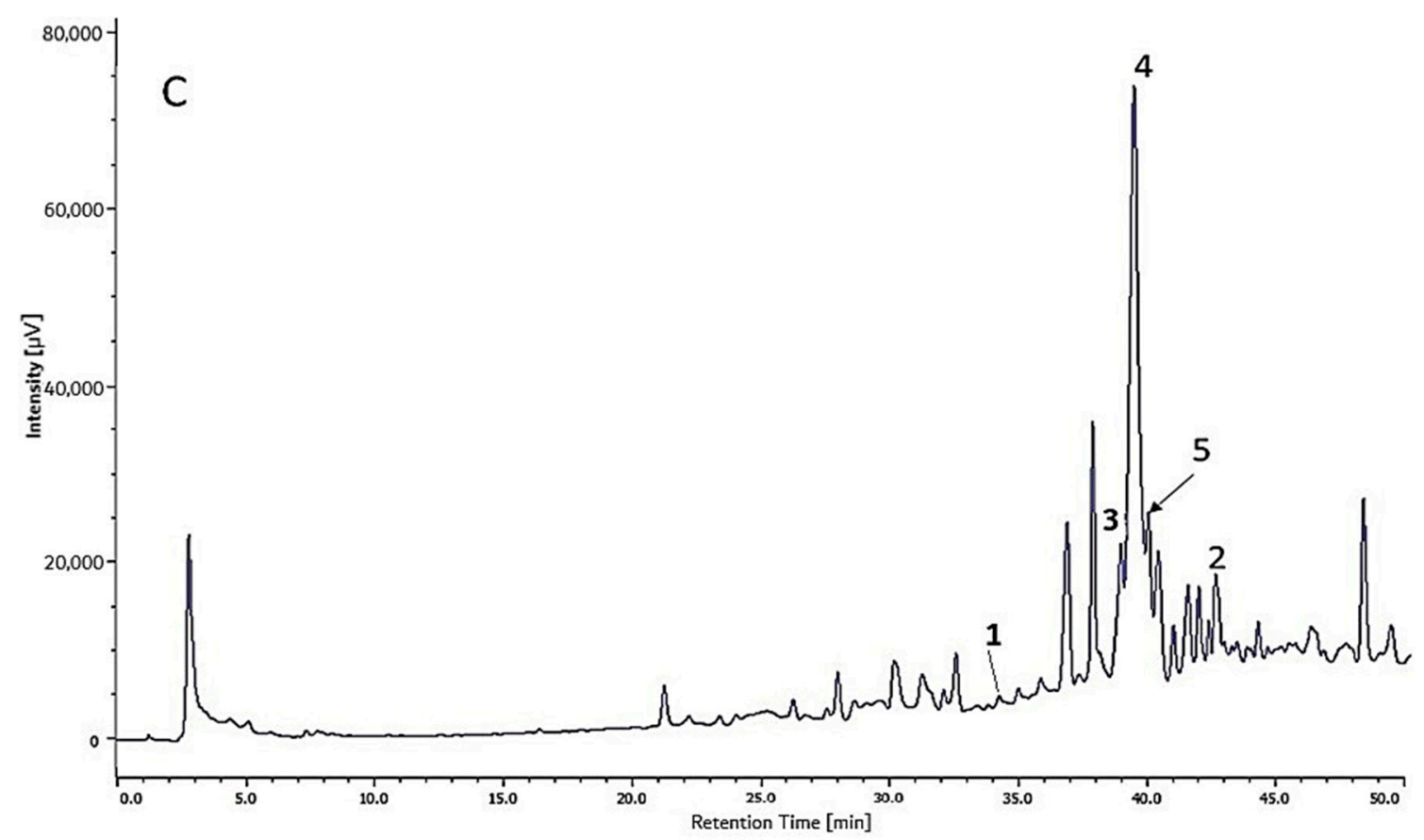

Figure 4. HPLC chromatogram: (A) ethanol extract of $M$. indica (EEM), (B) Ethanol extract of propolis (EEP) of P1 (T. sapiens Konawe Propolis), (C) EEP of P2 (T. Sapiens Kendari propolis).

M. indica trees that are around the nest emit reddish-brown sap (Figure 5a,b).

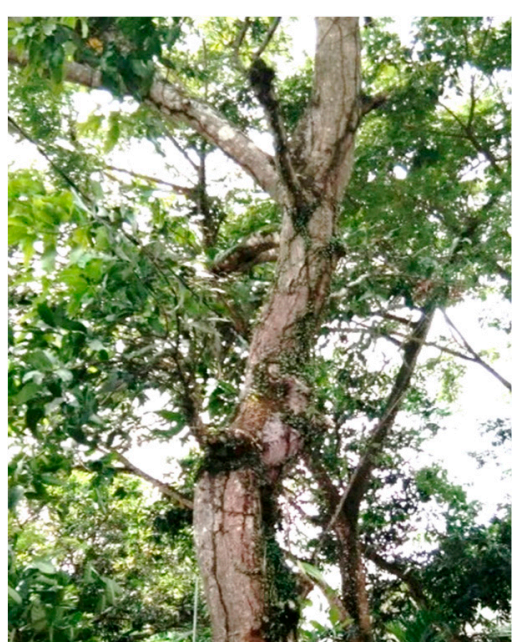

(a)

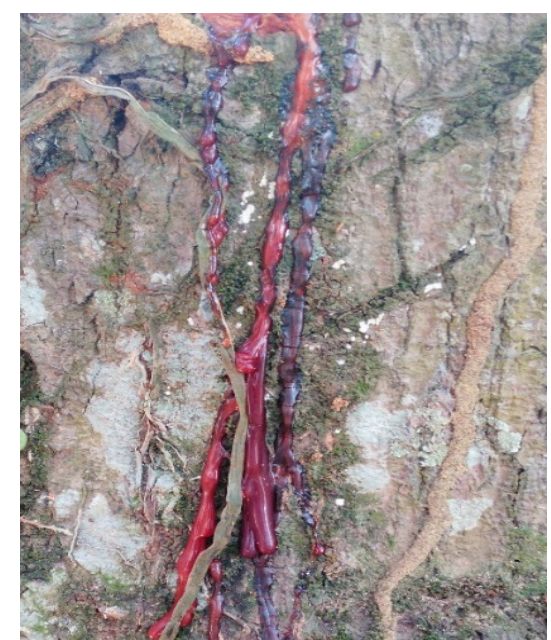

(b)

Figure 5. (a) Mangifera indica tree around T. sapiens bee hives in South Konawe and Kendari, Southeast Sulawesi, and (b) M. indica resin.

\section{Discussion}

3.1. Main Compounds of T. sapiens Bee Propolis from Jatibali, South Konawe (P1) and Kendari District (P2), Southeast Sulawesi

From all isolated compounds, four of them, cycloartenol (2), ambonic acid (3), mangiferonic acid (4), and ambolic acid (5), are the first cycloartane-type triterpenes found in Indonesian propolis (both Apidae and Melliponi bee propolis). A previous study conducted by Trusheva et al. [21] reported that other cycloarten-type triterpenes, mangiferolic acid, isomangiferolic acid, and 27-hydroxyimangiferolic 
acid had been found in propolis from East Jawa, Indonesia, different regions than Sulawesi, and different bees (Apis mellifera), but these were not Compounds 2, 3, 4, or 5 .

The constituent of this propolis is very similar to the components of Cameroonian (A. mellifera) propolis. All cycloartane-type triterpenes in this propolis were also found in the Cameroonian propolis. Some propolis from other tropical regions were also reported to contain cycloartane-type triterpenes. Myanmar (A. mellifera) propolis and Vietnam Trigona propolis are rich in cycloartane-triterpene compounds, both of which contain mangiferonic acid, 27-hydroxymangiferonic acid, and mangiferolic acid as the main constituents [26]. Malaysian propolis (Trigona itama) has cycloartenol [27]. Brazilian propolis contains cycloartane-type triterpenes, mangiferolic acid, 33-hydroxy-24-methylenecycloartane-26-oic acid, and ambonic and ambolic acid [25]. Thailand propolis contains dammarane triterpene, dipterocarpol, ursolic acid, and ocotillone [17].

It is interesting that, although the botanical origin of propolis from Myanmar, Vietnam, Malaysia, and Brazil is the same plant, $M$. indica, the cycloartane-type triterpenes contained in that propolis are not the same. Ambonic and ambolic acid are only found in Cameroonian propolis, Teresina (Brazil), and this propolis. This difference may be due to the $M$. indica variety is not the same from each region where the propolis originates.

P1 and P2 propolis showed different major compounds. Mangiferolic acid and cycloartenol acids are the major compounds in propolis from South Konawe; more than $80 \%$ of the ether fraction of this propolis is dominated by these two compounds (Figure 2 and Table 4). Ambonic, mangiferonic, and ambolic acid, meanwhile, are three compounds that are mostly present in propolis from the Kendari district (Figure 3 and Table 5). This difference may be due to the behavior of bees in collecting resins in colonies, species and varieties of plants, as well as differences in the parts and amount of resin taken. The composition of the secondary metabolites contained in each part of the plant such as shoots, leaves, branches, and stems is not the same even in one plant/tree. Bees can collect resin from the bud exudates or the sap that comes out of the wound on a branch or tree trunk. These results also indicate that the differences found between propolis samples from various regions are mainly due to differences in the flora and less to the species of the bees.

The study of bee propolis and its plant origin revealed a unique relationship between insects and plants. A study reported by Leonhardt [28,29] on six stingless-bee species (Tetragonilla collina, Tetragonula melanocephala, T. geissleri/laeviceps, T. melanocephala, Lepidotrigona terminata, Pariotrigona pendleburyi) in Borneo, Malaysia, found 113 terpenes in the nest, and 83 of them were also found on the surface of some of the bees' bodies. The terpenes were found to consist of sesquiterpenes and triterpenes, which represent the most prominent terpene class. This is a characteristic of the dipterocarp tree, the dominant family tree of Southeast Asian forests. The T. melanocephala, L. terminata, P. pendleburyi, and T. fuscobalteata species do not even have sesquiterpenes at all, but all species have triterpenes.

This study revealed the same thing about main propolis components from T. sapiens nests from the Sulawesi region, namely, triterpene. Even more uniquely, the main components of this propolis are in the same group of compounds, cycloartane-type triterpenes. Therefore, it is possible that stingless-bee species can specifically 'filter' resin derivative compounds, with some species not included in all compound classes, suggesting that terpene acquisition has a genetic basis in these bees [29]; specifically for this T. sapiens, it is triterpene.

\subsection{Botanical Origin of T. sapiens Propolis}

Compounds 1 and 2 were present in considerably more than $80 \%$ of the total area in the chromatogram obtained at $254 \mathrm{~nm}$ of the ether-soluble fraction of the propolis from South Konawe (Table 4), and Compounds 3, 4 , and $\mathbf{5}$ were more than $36 \%$ present of the total area in the chromatogram obtained at $254 \mathrm{~nm}$ of the ether-soluble fraction of the propolis from Kendari (Table 5). It is known that all cycloartane-type triterpenes in this propolis are also present in $M$. indica resin as its most common components [22]. This result was also confirmed by the peak HPLC chromatogram characteristic of 
the EEP and EEM, which showed the same pattern (Figure 4). It was concluded that the main propolis component came from $M$. indica resin. These results suggest that the predominant plant source of propolis in both Jatibali, South Konawe, and Kendari, Southeast Sulawesi could be M. indica (mango, Figure 5), which is widely present around where these bees' hives are located. By our observations, the $T$. sapiens bees frequently visited these plants.

This study characterized the botanical origin of propolis from Sulawesi for the first time. Although some of the components in this propolis have not been identified, the major compounds isolated from the propolis sample indicate that the main plant source is $M$. indica. Interestingly, some studies also show that some of the main propolis components are also present in mango resins. That is especially true for both Apis bee propolis and stingless-bee (Meliponi) propolis from the tropics. The botanical origin of A. mellifera bee propolis from Myanmar [26], Cameroon [23], and Indonesia [21] is reported to be M. indica. Likewise, the propolis of stingless bee T. spinipes from Brazil [30], Trigona itama from Malaysia [27], T. minor from Vietnam [18], and Tetragonula biroi from the Philippines, [31] was reported to have $M$. indica as its primary source.

In the tropics, many plants produce resins, and bees can collect these resins from various species around the nest, but several studies show that bees exhibit selective behavior and prioritize certain plant species during resin collection [32,33]. In this study, besides M. indica, several plants around the nest, such as Anacardium occidentale, Artocarpus cempedan, Euphorbia milii, Euphorbia pulcherima, and some flowering plants were also seen as visited by $T$. sapiens bees. However, the primary source of this propolis is the resin and bud exudates of $M$. indica, and it is convincing that $M$. indica is an important plant source of propolis in the tropics, not only in Asia but also in Africa and Central America.

Several studies have shown that the botanical origin of stingless-bee propolis in Southeast Asia forests is Dipterocarpaceae, which are rich in terpenes $[17,28]$. In this study, however, it was demonstrated that the origin of plant propolis is mango (Anacardiaceae). It seems that bees instinctively/genetically have the ability to recognize types of compounds in resin plants (in this case, triterpenes). So, what bees are looking for is not only focused on plant species, but also on specific compounds that exist in plant resins. The plant origin of propolis can be different, but its main components have similarities or are in the same group. Propolis samples in this study were obtained from apiaries around settlements and plantations where there are many mango plants. Thus, bees take advantage of the existence of this plant to collect resins and triterpenes to build their nests. Triterpenes have been known as secondary metabolites that have extensive biological activity. These compounds are mainly synthesized by plants to protect themselves from various attacks by disrupting organisms and diseases. Then, bees collect, choose, and use them to form propolis as a protective material for nests and colony members, a fascinating bee-plant interaction.

There have been some studies on the biological activity of these cycloartane-type triterpenes (23-hydroxyisomangiferolic acid) from Vietnam stingless-bee propolis (Trigona timor) and isoambolic acid from $M$. indica, which has strong preferential cytotoxicity to human pancreatic PAN-1 cancer cells $[18,34]$. Further research is needed to examine other biological activities of the isolated compounds in this study so more information could be obtained from this propolis and use it in the field of drug development from natural products.

\section{Materials and Methods}

\subsection{Materials}

Propolis samples were collected from the beehives of Tetragonula sapiens Cockerell, and Mangifera indica resin was collected from M. indica trees from September to November 2016 in Jatibali, South Konawe district (P1) and Kendari district (P2), Southeast Sulawesi, Indonesia (Figure 6a,b). They were identified by the Research Center for Biology, Indonesian Institute of Sciences, Bogor, Indonesia based on bee specimens, nest structures (Figure 7a) and the entrance tube form (Figure 7b). The two voucher samples of raw propolis, JK 0231 (South Konawe propolis) and JK 0232 (Kendari propolis), and the 
resin of M. indica (JK 0121) were deposited at the Faculty of Forestry and Environmental Sciences, Halu Oleo University, Kendari, Southeast Sulawesi, Indonesia.

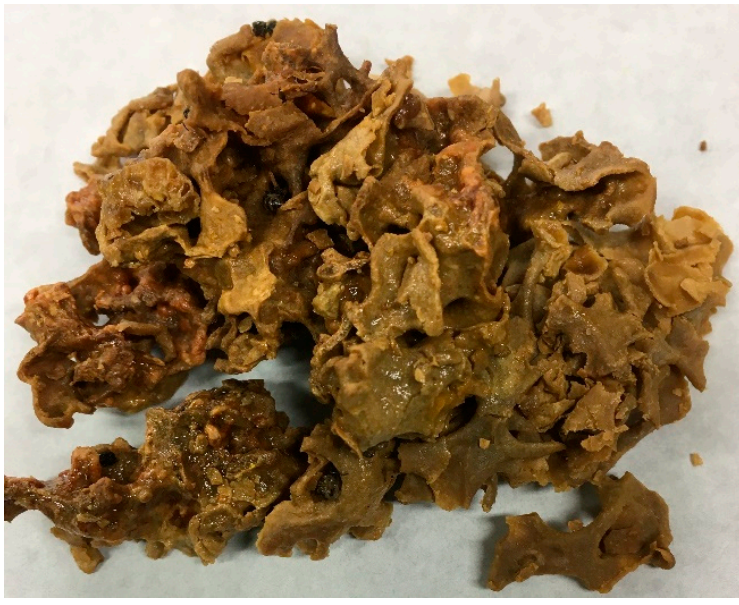

(a)

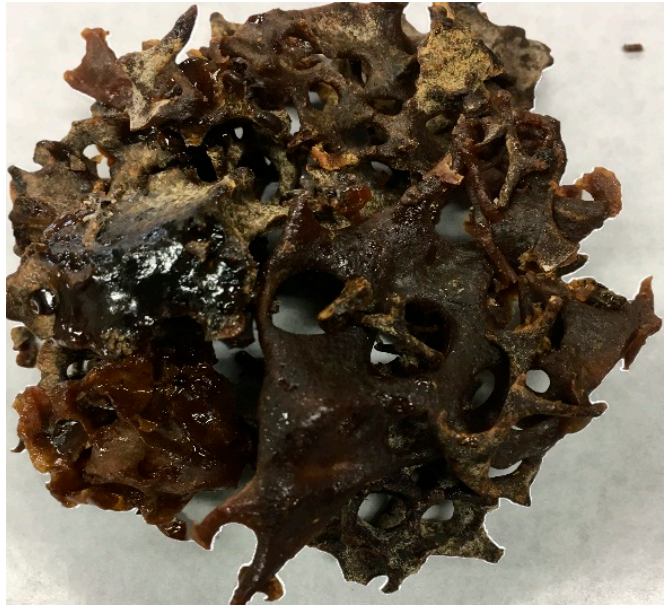

(b)

Figure 6. T. sapiens propolis from (a) South Konawe district and (b) Kendari district.

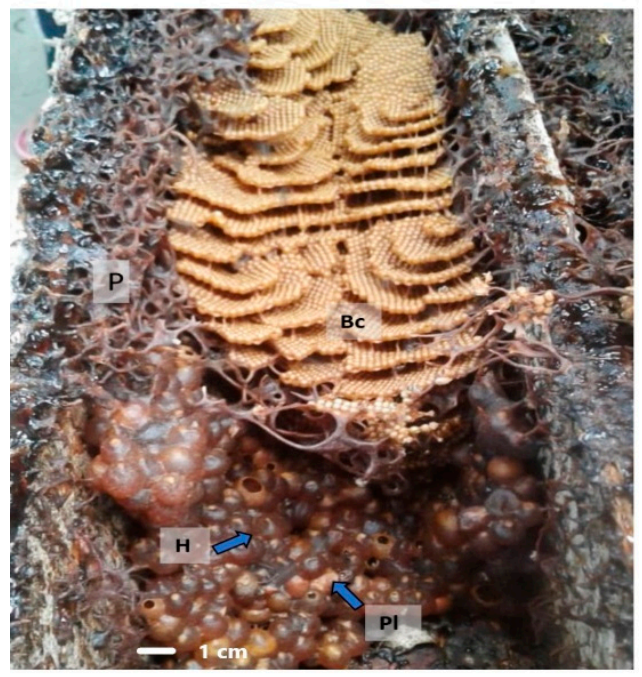

(a)

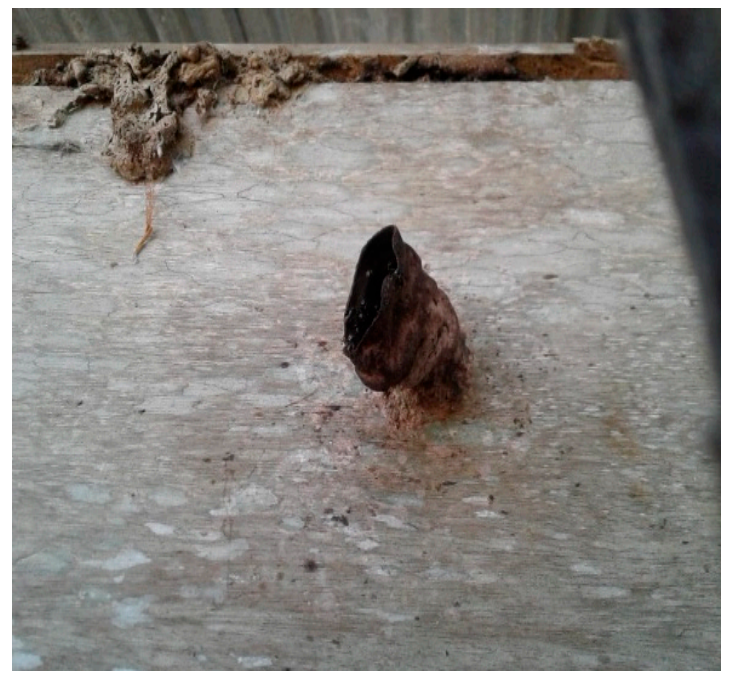

(b)

Figure 7. (a) T. sapiens nest: honey pots $(\mathrm{H})$, pollen pot $(\mathrm{Pl})$, brood cells $(\mathrm{Bc})$, and propolis $(\mathrm{P})$; (b) entrance tube of $T$. sapiens nest.

\subsection{Propolis and M. Indica Resin Extraction}

\subsubsection{Propolis from Jatibali, South Konawe District (P1)}

The raw P1 propolis sample (10 g) was ground to a fine powder that was extracted three times with $50 \mathrm{~mL}$ of $99 \%$ ethanol in a shaker at room temperature for $24 \mathrm{~h}$. After filtration of each extract with a filter paper (Advantec no. 2, $150 \mathrm{~mm}$ ), filtrates were combined, and this solution (EEP) was evaporated in vacuo with a rotary evaporator (Eyela CCA-1111, Tokyo Rikakikai, Tokyo, Japan). The P1 EEP (5.66 g) was partitioned between diethyl ether $(50 \mathrm{~mL})$ and ultrapure water $(50 \mathrm{~mL})$ with a separatory funnel to give an ether-soluble fraction $(4.87 \mathrm{~g})$ and an aqueous layer. The latter was again extracted with EtOAc, and the EtOAc-soluble fraction $(0.09 \mathrm{~g})$ and the aqueous fraction $(0.56 \mathrm{~g})$ were obtained. The ether-soluble and ethyl acetate-soluble fractions were washed with a saturated $\mathrm{NaCl}$ solution; then, the organic layer was dried over hydrous $\mathrm{Na}_{2} \mathrm{SO}_{4}$ before concentration. 


\subsubsection{Propolis from Kendari District (P2)}

The raw P2 propolis sample ( $15 \mathrm{~g})$ was ground to a fine powder that was extracted with the same method as P1 to obtain the P2 EEP. The EEP was partitioned between diethyl ether $(50 \mathrm{~mL})$ and ultrapure water $(50 \mathrm{~mL})$ with a separatory funnel to give an ether-soluble fraction $(7.35 \mathrm{~g})$ and an aqueous layer. The latter was again extracted with EtOAc to obtain an EtOAc-soluble fraction $(0.51 \mathrm{~g})$ and aqueous fraction $(0.57 \mathrm{~g})$.

\subsubsection{Indica Resin}

The $M$. indica resin sample $(2.0 \mathrm{~g})$ was ground into a fine powder then extracted three times with $20 \mathrm{~mL} 99 \%$ ethanol in a shaker at room temperature for $24 \mathrm{~h}$. After filtration using the same method as $\mathrm{P} 1$, an ethanol extract from $M$. indica resin (EEM, $1.176 \mathrm{~g}$ ) was obtained. The EEM was then applied to take HPLC (UV $254 \mathrm{~nm}$ ) profiles and compared with P1 and P2 EEP.

\subsection{TLC and HPLC Analysis}

Analytical thin-layer chromatography (TLC) and preparative TLC were performed on silica gel 60 $\mathrm{F}_{254}$ glass plates $(20 \times 20 \mathrm{~cm}$, thickness of 0.25 and $0.5 \mathrm{~mm}$, respectively (Merck, Damstardt, Germany)). Detection of the spot and bands was achieved under a UV-light shortwave of $254 \mathrm{~nm}$ (UVP, UVG-54, Upland, CA, USA). The bands corresponding to compounds were scratched off and eluted with a mixture of dichloromethane and $\mathrm{MeOH}$ (8:2). Analytical HPLC was performed with an HPLC system (a Jasco PU-980 intelligent HPLC Pump, a Jasco MD-2010 plus multiwavelength detector, a Jasco UV-970 intelligent UV/VIS detector, and a Jasco CO-965 column oven with a COSMOSIL packed column 5C-18-MS-II (ID $4.6 \times 250 \mathrm{~mm}$ ). Ten microliters of a solution of the propolis extract (1000 ppm) in $\mathrm{MeOH}$, filtered through a $0.45 \mu \mathrm{m}$ membrane filter, was injected into the injector of the HPLC system. The eluents were (A) $60 \% \mathrm{MeOH}$ and (B) $100 \% \mathrm{MeOH}$. The eluents were filtered through a $0.5 \mu \mathrm{m}$ membrane filter (PTFE). Separation was performed at $40{ }^{\circ} \mathrm{C}$ at a flow rate of $1 \mathrm{~mL} / \mathrm{min}$ for $50 \mathrm{~min}$ (retention time). Preparative HPLC was done using the same system as above with a different column size (COSMOSIL packed column 5C18-AR-II (ID $10 \times 250 \mathrm{~mm}$; pressure $54 \mathrm{~kg} / \mathrm{cm}^{2}$ ). Fractional separation was performed at $40{ }^{\circ} \mathrm{C}$ at a flow rate of $2 \mathrm{~mL} / \mathrm{min}$ with the following gradient: from (A) $80 \% \mathrm{MeOH}$ to (B) $100 \% \mathrm{MeOH}$ in 90 min. Column chromatography was performed with an FMI pump system (Yamazen, Osaka, Japan) with a column of silica gel 60 (Merck, 0.04-0.063 mm, 230-400 mesh), using a gradient system with ethyl acetate and $n$-hexane.

\subsection{NMR and Gas Chromatography-Mass Spectrometry (GC-MS) Analysis}

NMR spectra $\left({ }^{1} \mathrm{H},{ }^{13} \mathrm{C},{ }^{1} \mathrm{H}\right.$ COSY, HMBC, and HMQC) were recorded on a JEOL JNM ECA 600 FT-NMR spectrometer (600 MHz for ${ }^{1} \mathrm{H}$ and $150 \mathrm{MHz}$ for $\left.{ }^{13} \mathrm{C}\right)$ using chloroform-d $(99.8 \% \mathrm{D})$ as a solvent, with $0.03 \%$ tetramethylsilane (TMS) as an internal standard. Chemical shifts were expressed as $\delta$ (in ppm), and coupling constants $(J)$ were recorded in Hertz.

The molecular weight of the compounds was analyzed by GC-MS after silylation of the samples, which was done with a QP2010 SE gas chromatograph mass spectrometer (Shimadzu, Tokyo, Japan). The device was equipped with an Intercap 5MS fused silica capillary column (30 mm $\times 0.25 \mathrm{~mm}$ I.D. and $0.25 \mu \mathrm{m}$ film thickness), with an electronic pressure control module and a split/splitless injector (AOC 20i, Shimadzu). GC temperature was programmed from 100 to $310{ }^{\circ} \mathrm{C}$ at a rate of $5{ }^{\circ} \mathrm{C} / \mathrm{min}$, with helium as a carrier gas. The pressure was $100 \mathrm{kPa}$, split ratio was 1:80, the flow rate through the column was $1.33 \mathrm{~mL} / \mathrm{min}$ in constant flow mode, and the ionization voltage was $70 \mathrm{eV}$. Approximately $1 \mathrm{mg}$ of the propolis sample was mixed with $50 \mu \mathrm{L}$ of dry pyridine and $75 \mu \mathrm{L}$ of bis(trimethylsilyl) trifluoroacetamide. The mixture was heated at $80^{\circ} \mathrm{C}$ for $20 \mathrm{~min}$, and $1 \mu \mathrm{L}$ of the sample was injected. 


\subsection{Isolation Compounds of Propolis}

The ether-soluble fraction of P1 propolis was subjected to column chromatography on silica gel 60 (Merck, 40-60 $\mu \mathrm{m}, 230-400$ mesh) with stepwise elution of EtOAc/ $n$-hexane (50\%, 70\%, 90\%, and $100 \%)$. The eluates were concentrated in vacuo with a rotary evaporator to afford 5 major fractions (Fraction 1, 0.26 g; Fraction 2, 2.10 g; Fraction 3, 0.98 g; Fraction 4, 1.12 g; Fraction 5, 1.20 g). Fraction 3 $(977 \mathrm{mg})$ was dissolved in a small amount of EtOAc and subjected to TLC (EtOAc/ $n$-hexane $=1: 1(v / v))$ to give three subfractions (Fraction 3.1, $0.12 \mathrm{~g}$; Fraction 3.2, $0.83 \mathrm{~g}$; Fraction 3.3, $0.09 \mathrm{~g}$ ). Subfraction 3.2 $\left(830 \mathrm{mg}\right.$ ) was purified by preparative HPLC (eluent: $\mathrm{MeOH} / \mathrm{H}_{2} \mathrm{O}=80: 20(v / v)$ ), followed by repeated TLC and HPLC separation, to yield 4 sub-subfractions, Fraction 3.2.1, Fraction 3.2.2, Fraction 3.2.3, and Fraction 3.2.4. Fraction 3.2.4 (50.1 mg) was recrystallized with $\mathrm{MeOH} /$ acetone $(1: 1, v / v)$ to give 1 (20.6 mg).

Fraction $2(2.1 \mathrm{~g})$ from the ether extract of P1 was purified by preparative TLC with EtOAc/ $n$-hexane (30:70, $v / v$ ) to give 5 subfractions (2.1-2.5), in which Subfraction $2.3(484.1 \mathrm{mg})$ was separated by preparative TLC with EtOAc $/ n$-hexane (30:70, $v / v)$ to afford 3 subfractions (2.3.1-2.3.3), in which Fraction 2.3.1 (118 mg) was recrystallized with $\mathrm{MeOH} /$ acetone $(1: 1, v / v)$ to give $2(5.9 \mathrm{mg})$. The scheme of successive fractionations of T. sapiens of P1 is shown in Figure S1.

The ether soluble fraction of P2 propolis was subjected to column chromatography using the same method as P1. P2 eluates were concentrated in vacuo with a rotary evaporator to afford 5 major fractions (Fraction 1, 29 g; Fraction 2, 1.37 g; Fraction 3, 1.09 g; Fraction 4, 0.95 g; Fraction 5, 0.56 g). Fraction $3(1.09 \mathrm{~g})$ was dissolved in a small amount of EtOAc and subjected to TLC (EtOAc $/ n$-hexane $=$ $4: 6(v / v)$ ) to afford four subfractions (Fraction 3.1, $10.9 \mathrm{mg}$; Fraction 3.2, 254.4 mg; Fraction 3.3, $793.8 \mathrm{mg}$, and Fraction 3.4, $114.0 \mathrm{mg})$. Subfraction $3.2(254.4 \mathrm{mg})$ was recrystallized with $\mathrm{MeOH} /$ acetone (1:1, $v / v$ ) to give an inseparable mixture (137 $\mathrm{mg}$ ) of 3 and 4 (almost 1:1 ratio).

Fraction $4(0.95 \mathrm{~g})$ from P2 was purified by preparative RP-TLC with $100 \% \mathrm{MeOH}$, to give 4 subfractions (4.1-4.4), in which Subfraction $4.3(600.1 \mathrm{mg})$ was separated by preparative TLC with EtOAc/n-hexane (30:70, $v / v)$ to give three subfractions (4.31-4.3.3), in which Fraction 4.3.1 (118 mg) was recrystallized with $\mathrm{MeOH}$ /acetone (1:1) to give an inseparable mixture (24.8 mg) of $\mathbf{1}$ and $\mathbf{5}$ (almost 2:1 ratio). The scheme of successive fractionations of T. sapiens of P2 is shown in Figure S2.

Compound 1 (mangiferolic acid): white amorphous solid; Rf 0.40 in EtOAc/ $n$-hexane (4:6); MS-EI: $m / z 600[\mathrm{M}+2 \mathrm{TMS}]^{+}$, (calculated molecular weight for $\left.\mathrm{C}_{30} \mathrm{H}_{48} \mathrm{O}_{3}, 456.71\right) ;{ }^{1} \mathrm{H}$ NMR $\left(\mathrm{CDCl}_{3}\right)$ and ${ }^{13} \mathrm{C}$ $\operatorname{NMR}\left(\mathrm{CDCl}_{3}\right)$ (see Tables 1 and 2).

Compound 2 (cyloartenol): white amorphous solid; Rf 0.45 in EtOAc/ $n$-hexane (3:7); MS-EI: $m / z$ $570[\mathrm{M}+2 \mathrm{TMS}]^{+}$, (calculated molecular weight for $\left.\mathrm{C}_{30} \mathrm{H}_{50} \mathrm{O}, 426.72\right){ }^{1} \mathrm{H} \mathrm{NMR}\left(\mathrm{CDCl}_{3}\right)$ and ${ }^{13} \mathrm{C} \mathrm{NMR}$ $\left(\mathrm{CDCl}_{3}\right)$ (see Tables 1 and 2$)$.

Compound 3 (ambonic acid): white amorphous solid; Rf 0.5 in in EtOAc/ $n$-hexane (4:6); MS-EI: $m / z 612\left[\mathrm{M}+2 \mathrm{TMS}^{+}\right.$, (calculated molecular weight for $\left.\mathrm{C}_{30} \mathrm{H}_{50} \mathrm{O}, 469.36\right){ }^{1} \mathrm{H} \mathrm{NMR}\left(\mathrm{CDCl}_{3}\right)$ and ${ }^{13} \mathrm{C}$ $\operatorname{NMR}\left(\mathrm{CDCl}_{3}\right)$ (see Tables 1 and 2).

Compound 4 (mangiferonic acid): white amorphous solid; Rf 0.5 in in EtOAc/n-hexane (4:6); MS-EI: $m / z 598[\mathrm{M}+2 \mathrm{TMS}]^{+}$, (calculated molecular weight for $\left.\mathrm{C}_{30} \mathrm{H}_{50} \mathrm{O}, 454.37\right){ }^{1} \mathrm{H}$ NMR $\left(\mathrm{CDCl}_{3}\right)$ and ${ }^{13} \mathrm{C}$ NMR $\left(\mathrm{CDCl}_{3}\right)$ (see Tables 1 and 2$)$.

Compound 5 (ambolic acid): white amorphous solid; Rf 0.35 in $100 \% \mathrm{MeOH}$ (RP-TLC); MS-EI: $\mathrm{m} / \mathrm{z} 616[\mathrm{M}+2 \mathrm{TMS}]^{+}$, (calculated molecular weight for $\left.\mathrm{C}_{30} \mathrm{H}_{50} \mathrm{O}, 472.38\right){ }^{1} \mathrm{H} \mathrm{NMR}\left(\mathrm{CDCl}_{3}\right)$ and ${ }^{13} \mathrm{C}$ $\operatorname{NMR}\left(\mathrm{CDCl}_{3}\right)$ (see Tables 1 and 2).

\section{Conclusions}

The major compounds of T. sapiens bee propolis from Southeast Sulawesi, Indonesia were isolated and identified as five cycloartane-type triterpenes, namely, mangiferolic acid, cycloartenol, and ambonic, mangiferonic, and ambolic acid. The plant source of the propolis from Southeast Sulawesi was suggested to be $M$. indica. 
Supplementary Materials: The following are available online at http:/ / www.mdpi.com/2223-7747/8/3/57/s1. Figure S1: Scheme of successive fractionations of T. sapiens propolis from Jatibali, South Konawe, Southeast Sulawesi (P1); Figure S2: Scheme of successive fractionations of T. sapiens propolis from Kendari, Southeast Sulawesi (P2); Figure S3: ${ }^{13} \mathrm{C}$ NMR (150 MHz) and ${ }^{1} \mathrm{H}$ NMR spectra $\left(600 \mathrm{MHz}, \mathrm{CDCl}_{3}\right)$ of Compounds 1, 2, 3, 4 and 5 .

Author Contributions: N.P. and T.S. designed the experiments; N.P. performed the experiments, analyzed the data, and wrote the paper; and T.S. and T.K. supervised.

Funding: This work was supported by a grant from Beasiswa Unggulan Dosen Indonesia-Luar Negeri (BUDI-LN) 2016 (No. PRJ-3619/LPDP.3/2016), funded by the Indonesian Endowment Fund for Education (LPDP), Ministry of Finance of Indonesia and Directorate General of Resources for Science, Technology, and Higher Education of the Ministry of Research, Technology, and Higher Education of Indonesia (Ristekdikti).

Acknowledgments: This work is a part of doctoral research. The authors thank all those who contributed to this research, all members of the Biomass Chemistry Laboratory, Faculty of Agriculture, Kagawa University, including the Dean of United Graduate School of Agricultural Sciences Ehime University, Japan. We are grateful to Dr. Sih Kahono, M. Sc., from the Entomology Laboratory, Research Center for Biology, Indonesian Institute of Sciences, Bogor, Indonesia for the identification of the stingless bee. We also thank Made Ray and Made Buda from South Konawe District, and Pono Suderajad from Kendari, Southeast Sulawesi for their T. sapiens propolis and bee specimens.

Conflicts of Interest: The authors declare no conflict of interest.

\section{References}

1. Ghisalberti, E.L. Propolis: A review. Bee World 1979, 60, 59-84. [CrossRef]

2. Popova, M.; Silici, S.; Kaftanoglu, O.; Bankova, V. Antibacterial activity of turkish propolis and its qualitative and quantitative chemical composition. Phytomedicine 2005, 12, 221-228. [CrossRef] [PubMed]

3. Pujirahayu, N.; Ritonga, H.; Laksananny, S.A.; Uslinawaty, Z. Antibacterial activity of oil extract of trigona propolis. Int. J. Pharm. Pharm. Sci. 2015, 7, 419-422.

4. Marcucci, M.C. Propolis: Chemical composition, biological properties and therapeutic activity. Apidologie 1995, 26, 83-99. [CrossRef]

5. Dantas Silva, R.P.; Machado, B.A.S.; Barreto, G.d.A.; Costa, S.S.; Andrade, L.N.; Amaral, R.G.; Carvalho, A.A.; Padilha, F.F.; Barbosa, J.D.V.; Umsza-Guez, M.A. Antioxidant, antimicrobial, antiparasitic, and cytotoxic properties of various brazilian propolis extracts. PLoS ONE 2017, 12, e0172585. [CrossRef] [PubMed]

6. Schnitzler, P.; Neuner, A.; Nolkemper, S.; Zundel, C.; Nowack, H.; Sensch, K.H.; Reichling, J. Antiviral activity and mode of action of propolis extracts and selected compounds. Phytother. Res. 2010, 24, S20-S28. [CrossRef] [PubMed]

7. Paulino, N.; Abreu, S.R.L.; Uto, Y.; Koyama, D.; Nagasawa, H.; Hori, H.; Dirsch, V.M.; Vollmar, A.M.; Scremin, A.; Bretz, W.A. Anti-inflammatory effects of a bioavailable compound, artepillin c, in brazilian propolis. Eur. J. Pharmacol. 2008, 587, 296-301. [CrossRef]

8. Sawicka, D.; Car, H.; Borawska, M.H.; Nikliński, J. The anticancer activity of propolis. The anticancer activity of propolis. Folia Histochem. Cytobiol. 2012, 50, 25-37. [CrossRef]

9. Bayram, S.; Ecem Bayram, N.; Gerçek, Y.; Aydogan, M.; Cevahir Oz, G. Chemical analysis and antimicrobial effect of propolis from hakkari province of turkey against some pathogenic microorganisms. Eur. J. Biol. 2017, 76, 74-78. [CrossRef]

10. Roubik, D.W. Stingless bee nesting biology. Apidologie 2006, 37, 124-143. [CrossRef]

11. Michener, C.D. The Bees of the World; The John Hopkins University Press: Baltimore, MD, USA; London, UK, 2000; Volume 78, p. 353. ISBN 0-8018-6133.

12. Biesmeijer, J.C.; Slaa, E.J. Information flow and organization of stingless bee foraging. Apidologie 2004, 35, 143-157. [CrossRef]

13. Suriawanto, N.; Atmowidi, T.; Kahono, S. Nesting sites characteristics of stingless bees (hymenoptera: Apidae) in central sulawesi, indonesia. J. Insect Biodivers. 2017, 5, 1-9. [CrossRef]

14. Rasmussen, C.; Cameron, S.A. Molecular phylogeny of the old world stingless bees (hymenoptera: Apidae: Meliponini) and the non-monophyly of the large genus trigona. Syst. Entomol. 2007, 32, 26-39. [CrossRef]

15. Velikova, M.; Bankova, V.; Tsvetkova, I.; Kujumgiev, A.; Marcucci, M.C. Antibacterial ent-kaurene from brazilian propolis of native stingless bees. Fitoterapia 2000, 71, 693-696. [CrossRef] 
16. Da Cunha, M.G.; Franchin, M.; Galvão, L.; de Ruiz, A.; de Carvalho, J.E.; Ikegaki, M.; de Alencar, S.M.; Koo, H.; Rosalen, P.L.J.A. Antimicrobial and antiproliferative activities of stingless bee melipona scutellaris geopropolis. BMC Complement. Altern. Med. 2013, 13, 23. [CrossRef] [PubMed]

17. Sanpa, S.; Popova, M.; Bankova, V.; Tunkasiri, T.; Eitssayeam, S.; Chantawannakul, P. Antibacterial compounds from propolis of tetragonula laeviceps and tetrigona melanoleuca (hymenoptera: Apidae) from thailand. PLoS ONE 2015, 10, e0126886. [CrossRef] [PubMed]

18. Nguyen, H.X.; Nguyen, M.T.T.; Nguyen, N.T.; Awale, S. Chemical constituents of propolis from vietnamese trigona minor and their antiausterity activity against the panc-1 human pancreatic cancer cell line. J. Nat. Prod. 2017, 80, 2345-2352. [CrossRef]

19. Popova, M.P.; Chinou, I.B.; Marekov, I.N.; Bankova, V.S. Terpenes with antimicrobial activity from cretan propolis. Phytochemistry 2009, 70, 1262-1271. [CrossRef]

20. Kumazawa, S.; Nakamura, J.; Murase, M.; Miyagawa, M.; Ahn, M.-R.; Fukumoto, S.J.N. Plant origin of okinawan propolis: Honeybee behavior observation and phytochemical analysis. Naturwissenschaften 2008, 95, 781. [CrossRef]

21. Trusheva, B.; Popova, M.; Koendhori, E.B.; Tsvetkova, I.; Naydenski, C.; Bankova, V. Indonesian propolis: Chemical composition, biological activity and botanical origin. Nat. Prod. Res. 2011, 25, 606-613. [CrossRef]

22. Anjaneyulu, V.; Satyanarayana, P.; Viswanadham, K.N.; Jyothi, V.G.; Rao, K.N.; Radhika, P. Triterpenoids from mangifera indicafn1fn1part iii in the series triterpenoids from mangifera indica. Phytochemistry 1999, 50, 1229-1236. [CrossRef]

23. Kardar, M.N.; Zhang, T.; Coxon, G.D.; Watson, D.G.; Fearnley, J.; Seidel, V. Characterisation of triterpenes and new phenolic lipids in cameroonian propolis. Phytochemistry 2014, 106, 156-163. [CrossRef]

24. Escobedo-Martínez, C.; Concepción Lozada, M.; Hernández-Ortega, S.; Villarreal, M.L.; Gnecco, D.; Enríquez, R.G.; Reynolds, W. $1 \mathrm{~h}$ and $13 \mathrm{c} \mathrm{nmr}$ characterization of new cycloartane triterpenes from mangifera indica. Magn. Reson. Chem. 2012, 50, 52-57. [CrossRef]

25. Da Silva, M.D.; Citó, M.G.; Chaves, M.H.; Lopes, J.A. Triterpenóides tipo cicloartano de própolis de teresina-pi. Química Nova 2005, 28, 801-804. [CrossRef]

26. Li, F.; Awale, S.; Zhang, H.; Tezuka, Y.; Esumi, H.; Kadota, S. Chemical constituents of propolis from myanmar and their preferential cytotoxicity against a human pancreatic cancer cell line. J. Nat. Prod. 2009, 72, 1283-1287. [CrossRef]

27. Zayyanu, U.U.; Mohamed, M. Analysis of phytochemical compounds in water and ethanol extracts of malaysian propolis. Int. J. Pharm. Biol. Sci. 2015, 6, 374-380.

28. Leonhardt, S.D.; Schmitt, T.; Blüthgen, N. Tree resin composition, collection behavior and selective filters shape chemical profiles of tropical bees (apidae: Meliponini). PLoS ONE 2011, 6, e23445. [CrossRef] [PubMed]

29. Leonhardt, S.D.; Blüthgen, N.; Schmitt, T. Chemical profiles of body surfaces and nests from six bornean stingless bee species. J. Chem. Ecol. 2011, 37, 98-104. [CrossRef] [PubMed]

30. Freitas, M.O.; Ponte, F.A.F.; Lima, M.A.S.; Silveira, E.R. Flavonoids and triterpenes from the nest of the stingless bee trigona spinipes. J. Braz. Chem. Soc. 2008, 19, 532-535. [CrossRef]

31. Alvarez, P.L.; Cruz, M.B.; Micor, J.R.; Fajardo, A.C., Jr.; Cervancia, C.R.; Hizon-Fradejas, A.B. Identification of flavonoids and phenolic compounds in propolis from stingless bee (Tetragonula biroi friese) nests and extracts from five tree sources using tandem liquid chromatography-mass spectrometry. Philipp. Entomol. 2014, 27, 91-99.

32. Isidorov, V.A.; Szczepaniak, L.; Bakier, S. Rapid gc/ms determination of botanical precursors of eurasian propolis. Food Chem. 2014, 142, 101-106. [CrossRef] [PubMed]

33. Okińczyc, P.; Szumny, A.; Szperlik, J.; Kulma, A.; Franiczek, R.; Żbikowska, B.; Krzyżanowska, B.; Sroka, Z. Profile of polyphenolic and essential oil composition of polish propolis, black poplar and aspens buds. Molecules 2018, 23, 1262. [CrossRef] [PubMed]

34. Nguyen, H.X.; Do, T.N.V.; Le, T.H.; Nguyen, M.T.T.; Nguyen, N.T.; Esumi, H.; Awale, S. Chemical constituents of mangifera indica and their antiausterity activity against the panc- 1 human pancreatic cancer cell line. J. Nat. Prod. 2016, 79, 2053-2059. [CrossRef] [PubMed]

(C) 2019 by the authors. Licensee MDPI, Basel, Switzerland. This article is an open access article distributed under the terms and conditions of the Creative Commons Attribution (CC BY) license (http:/ / creativecommons.org/licenses/by/4.0/). 